\title{
POTENSI LIKUIFAKSI DI PESISIR BARAT SUMATERA MENGGUNAKAN SONDIR
}

\author{
Herdiana Mutmainah (iD \\ Loka Riset Sumberdaya dan Kerentanan Pesisir \\ J1. Raya Padang Painan KM.16. Padang. Sumatera Barat, 25237 \\ E-mail: herdianamute77@gmail.com
}

\begin{abstract}
ABSTRAK
Peristiwa gempa umumnya diikuti oleh serangkaian guncangan dan sesar tanah di permukaan. Gempa rawan terjadi pada lokasi yang dilalui jalur patahan dan tumbukan lempeng tektonik aktif. Pantai barat Sumatera berada di jalur patahan Semangko dan perbatasan lempeng tektonik aktif Eurasia dan Australia-Hindia. Gempa di atas skala 5,5 SR memicu likuifaksi pada tanah granuler dan muka air tanah dangkal. Kabupaten Agam dan Kabupaten Pasaman Barat di pesisir barat Provinsi Sumatera Barat merupakan lokasi yang rawan likuifaksi. Gempa Padang pada tahun 2009 (7,9 SR) berdampak memicu likuifaksi di kedua kabupaten tersebut. Penelitian ini bertujuan untuk menganalisa potensi likuifaksi di Kabupaten Agam dan Kabupaten Pasaman Barat. Penelitian dilakukan pada Oktober 2019 berdasarkan metode faktor aman menggunakan sondir (Cone Penetration Test/CPT) di 3 (tiga) desa yaitu Desa Tiku (Kabupaten Agam), Desa Air Bangis dan Desa Sasak (Kabupaten Pasaman Barat). Hasil penelitian menunjukkan Gempa 7 SR sudah mampu memicu likuifaksi $(\mathrm{SF}<1,0)$ di Desa Air Bangis dan Desa Sasak sedangkan simulasi Gempa Padang tahun 2009 (7,9 SR) menunjukkan potensi likuifaksi di Desa Tiku adalah SF =0,53 - 0,95; Desa Air Bangis $S F=0,51-0,97$ dan Desa Sasak SF =0,45-0,95.
\end{abstract}

Kata Kunci : Likuifaksi, Gempa, Sondir, Pesisir, Agam, Pasaman Barat

\section{PENDAHULUAN}

Likuifaksi menjadi fenomena di Indonesia akhirakhir ini karena tidak hanya besarnya kerusakan dan kerugian yang ditimbulkan namun juga cepatnya kejadian sehingga menyulitkan evakuasi. Likuifaksi di sebagian wilayah Indonesia umumnya terjadi di wilayah subduksi lempeng tektonik aktif (Hardy, dkk., 2015) setelah gempa di atas skala 5,5 SR seperti Palu, Lombok, Yogyakarta, Aceh dan Sumatera Barat (Soebowo, dkk., 2014). Likuifaksi menyebabkan bangunan runtuh karena kegagalan pondasi dangkal (Richards, dkk.,1993 dalam Karamitros, dkk.,2013; Bray \& Macedo, 2017). Sedangkan fondasi dangkal hanya diperbolehkan untuk jenis tanah yang memadai (Karamitros,dkk.,2013). Penurunan bangunan akibat likuifaksi disebabkan oleh beberapa faktor yaitu kuat gempa, lokasi dan karakteristik bangunan (Bray \& Macedo, 2017). Likuifaksi adalah perubahan bentuk pada tanah granular dari bentuk solid menjadi cair akibat naiknya tekanan air pori dan hilangnya tegangan efektif. Likuifaksi disebabkan oleh beban statis atau dinamis pada tanah berpasir jenuh air yang menyebabkan berbagai kerusakan pondasi, struktur dan lain-lain (Bao, dkk., 2019). Likuifaksi tidak hanya terjadi pada tanah berpasir jenuh air tetapi juga pada campuran tanah dan bijih besi tidak jenuh air, dengan densitas rendah dan gradasi baik selama pelayaran, walaupun belum diketahui penyebabnya secara pasti (Kwa \& Airey, 2019). Gempa akibat erupsi Gunung Agung 6 SR memicu likuifaksi di Bali Selatan pada lapisan tanah lumpur berpasir dan tanah liat berlumpur (Sinarta dan Basoka, 2019). Indeks
Potensi Likuifaksi dan faktor aman likuifaksi mengunakan alat Standard Penetration Test (SPT) untuk tanah dalam (Widyaningrum, 2012; Mina, dkk, 2018). Likuifaksi menggunakan alat sonder atau Cone Penetration Test (CPT) berdasarkan nilai faktor aman (Ikhsan, 2011; Lonteng, dkk, 2011) menganalisa 1. Keseluruhan metode tersebut didasarkan pada perbandingan nilai Cyclic Retention Ratio (CRR) dan Cyclic Stress Ratio (CSR) yang pada dasarnya merupakan metode semi empiris). Untuk mengurangi risiko likuifaksi, dilakukan percobaan grouting jet pile mikro menggunakan pasir bersih dan menunjukkan hasil berupa peningkatan parameter tanah dan naiknya faktor aman berdasarkan beberapa metode analisis (Farhangi, dkk 2020).

KabupatenAgam dan Kabupaten Pasaman Barat terletak di pesisir barat Sumatera Barat yang merupakan kawasan subduksi sehingga rawan gempa yang dapat memicu likuifaksi. Gempa Padang tahun 2009 (7,9 SR) menyebabkan likuifaksi di sebagian kawasan kedua kabupaten tersebut. Kabupaten Agam dan Kabupaten Pasaman Barat merupakan kawasan padat penduduk dan menjadi pusat aktivitas ekonomi serta perbatasan dan jalur utama lintas propinsi (LRSDKP, 2019). Belum ada penelitian tentang likuifaksi di kedua kabupaten tersebut. Untuk mengantisipasi kerugian yang lebih besar dan sebagai upaya mitigasi maka dilakukan penelitian potensi likuifaksi di kedua kabupaten tersebut. 


\section{RUANG LINGKUP}

Ruang lingkup penelitian ini adalah pesisir Kabupaten Pasaman Barat yang meliputi 3 (tiga) desa di yaitu Desa Tiku (Kabupaten Agam); Desa Air Bangis dan Desa Sasak (Kabupaten Pasaman Barat). Analisis menggunakan metode semi empiris berupa analisis faktor aman menggunakan alat sondir. Penelitian ini bertujuan untuk mengetahui potensi likuifaksi suatu daerah berdasarkan nilai faktor aman.

\section{BAHAN DAN METODE}

Bahan yang digunakan adalah sampel tanah di lokasi penelitian. Pengambilan sampel tanah dilakukan secara purposive sampling. Sampel tanah diukur di Laboratorium Mekanika Tanah Universitas Negeri Padang untuk memperoleh diameter dan gradasi butiran tanah. Metode yang digunakan adalah cyclic ratio dengan membandingkan Cyclic Retention Ratio (CRR) terhadap Cyclic Stress Ratio (CSR) sehingga diperoleh nilai faktor aman. Alat yang digunakan adalah sondir atau Cone Penetration Test (CPT). Sondir digunakan untuk memperoleh parameter kedalaman lapisan tanah, daya dukung tanah (qc) dan nilai friksi (fr) pada tanah dangkal. Survey dilakukan pada 25-27 Oktober 2019 di 3 (tiga) lokasi yaitu Desa Tiku (Kabupaten Agam), Desa Sasak dan Desa Air Bangis (Kabupaten Pasaman Barat). Gambar 1 adalah peta lokasi penelitian yaitu Desa Tiku $\left(0^{\circ} 23^{\prime} 52.91^{\prime \prime}\right.$ LS dan 9955'6.72" BT), Desa Sasak $\left(0^{\circ} 1\right.$ '52.22" LS dan 99³9'51.48" BT) dan Desa Air Bangis $\left(0^{\circ} 11^{\prime} 56.47^{\prime \prime} \mathrm{LU}\right.$ dan 99²2'33.56" BT). Gambar 2 menunjukkan diagram alir penelitian.

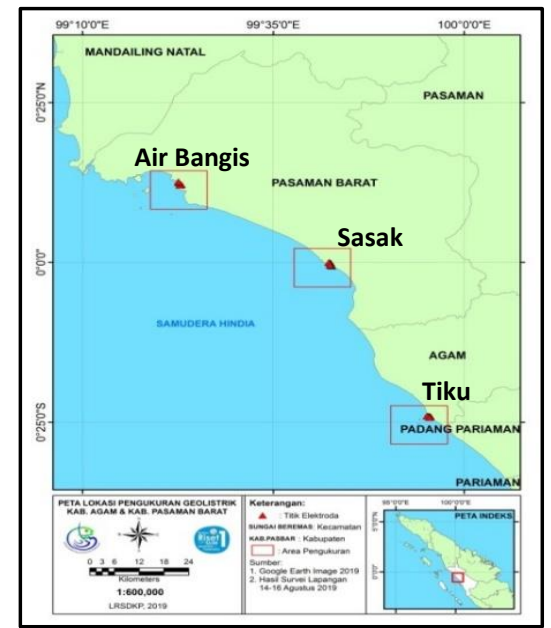

Gambar 1. Lokasi penelitian likuifaksi di Kabupaten Agam dan Kabupaten Pasaman Barat

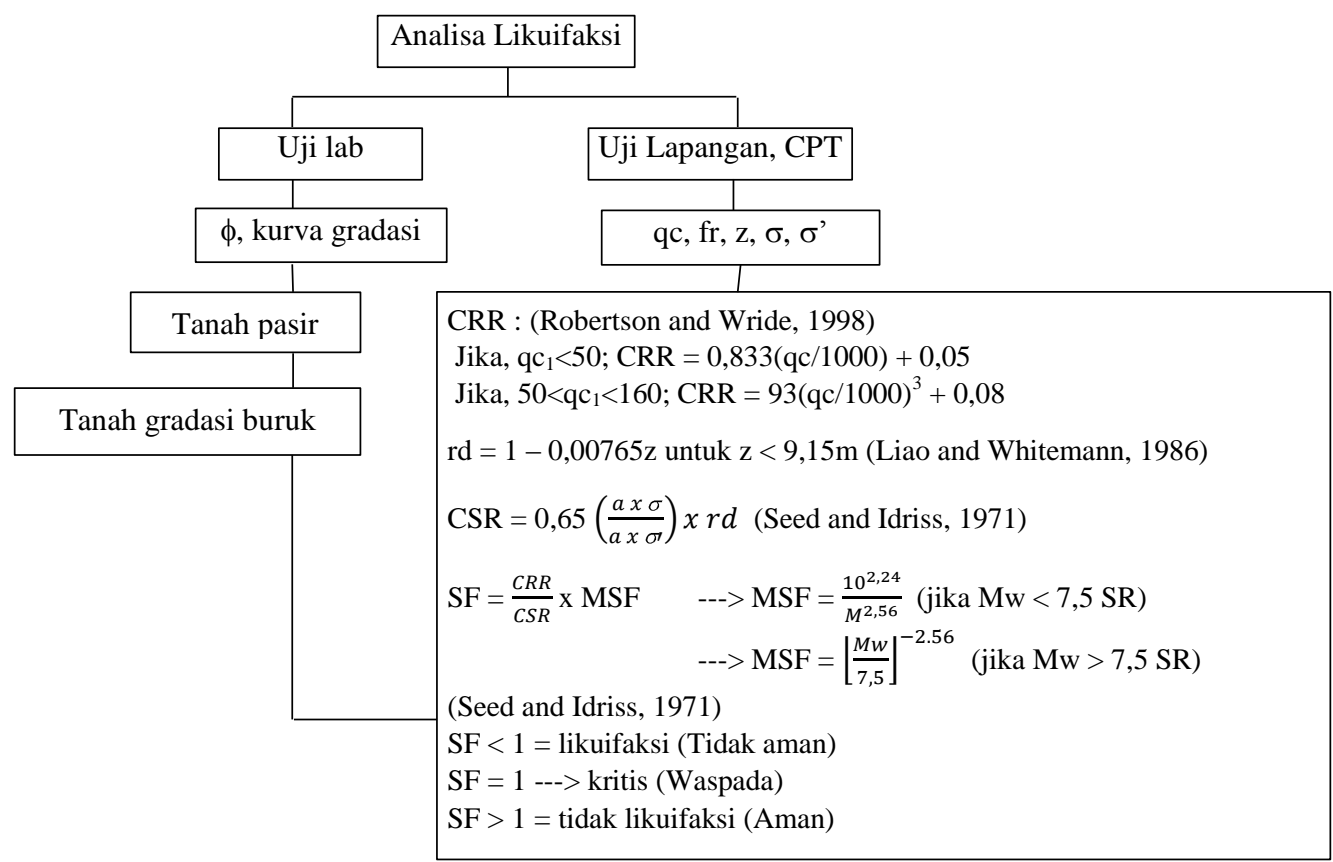

Gambar 2. Diagram Alur Analisis Likuifaksi 


\section{PEMBAHASAN}

Analisis likuifaksi melalui tahapan penilaian distribusi butiran tanah, jarak episentrum gempa terhadap lokasi penelitian dan nilai faktor aman berdasarkan perbandingan cyclic ratio.

\subsection{Diameter Butiran dan Kurva Gradasia}

Sampel tanah yang diambil menggunakan sondir atau CPT kemudian dianalisis di laboratorium mekanika tanah untuk mengetahui klasifikasi jenis dan kondisi tanah berdasarkan diameter butiran dan gradasi. Gambar 3 adalah rentang distribusi tanah di lokasi penelitian yang berpotensi likuifaksi atau bergradasi buruk. Gambar 3 menunjukkan bahwa ketiga lokasi berpotensi likuifaksi.

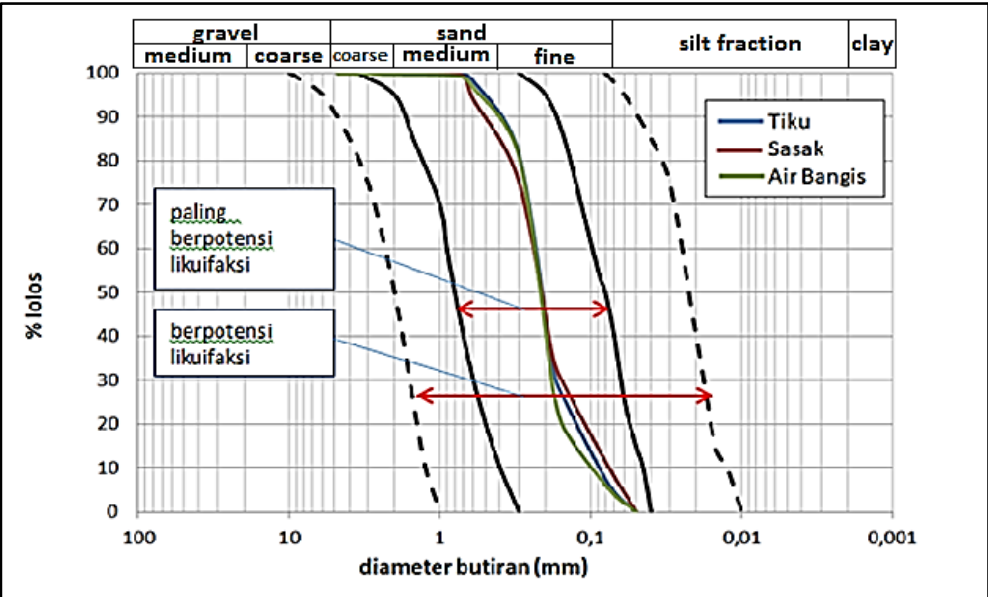

\section{Gambar 3. Potensi Likuifaksi di Ketiga Lokasi (Tiku, Sasak dan Air Bangis) Berdasarkan Gradasi Butiran}

\subsection{Hubungan Jarak Episentrum dengan Momen Gempa}

Jarak episentrum gempa terhadap suatu lokasi berpengaruh pada potensi likuifaksi di lokasi tersebut. Gambar 4 menunjukkan jarak episentrum Gempa Padang tahun 2009 (7,9 SR) terhadap lokasi penelitian.

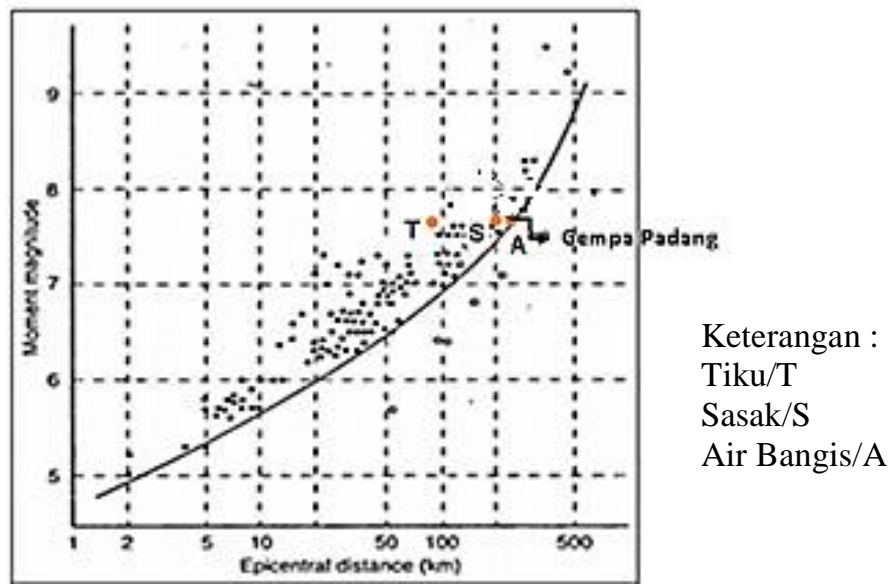

Gambar 4. Jarak Episentrum Gempa Padang Terhadap Lokasi Penelitian

Diketahui parameter $\mathrm{qc}=\mathrm{qc} 1 \mathrm{~N} ; \mathrm{a}=0,12 \mathrm{~g}(\mathrm{SNI} 1726: 2012) ; \mathrm{g}=9,81 \mathrm{~m} / \mathrm{det}$. Perhitungan nilai tegangan total dan tegangan aktif ketiga lokasi seperti tercantum dalam Tabel 1.

Tabel 1. Tegangan Tanah

\begin{tabular}{|c|c|c|c|}
\hline Tegangan (Mpa) & Tiku & Sasak & Air Bangis \\
\hline$\sigma_{\text {total }}(\sigma)$ & $1,13 \mathrm{z}$ & $1,36 \mathrm{z}$ & $1,62 \mathrm{z}$ \\
\hline$\sigma_{\text {efektif }}\left(\sigma^{\prime}\right)$ & $0,897 \mathrm{z}$ & $1,013 \mathrm{z}$ & $1,23 \mathrm{z}$ \\
\hline
\end{tabular}

Sumber: Lab Mektan UNP 


\subsection{Nilai Faktor Aman}

Perhitungan parameter likuifaksi untuk memperoleh nilai faktor aman/Safety Factor (SF). Rata-rata kejadian likuifaksi di Indonesia disebabkan oleh gempa skala 7 SR hingga 9 SR. Nilai faktor aman likuifaksi Desa Tiku untuk gempa 7 SR hingga 9 SR seperti tercantum dalam Tabel 2 hingga Tabel 5. Sedangkan nilai faktor aman likuifaksi Desa Air Bangis untuk gempa 7 SR hingga 9 SR seperti tercantum dalam Tabel 6 hingga Tabel 9. Nilai faktor aman likuifaksi Desa Sasak untuk gempa 7 SR hingga 9 SR seperti tercantum dalam Tabel 10 hingga Tabel 13.

1. Desa Tiku

Sondir di Desa Tiku dilakukan hingga kedalaman 2,0 m dengan interval 0,2 m. Simulasi dilakukan menggunakan gempa magnitudo 7 SR - 9 SR. Tabel 2 menunjukkan nilai angka aman untuk simulasi gempa 7 SR. Nilai faktor aman untuk gempa 7 SR berkisar antara 1,01-1,30. Gempa skala 7 SR belum memicu likuifaksi di Desa Tiku.

Tabel 2. Momen Gempa 7 SR terhadap Nilai Faktor Aman (SF) di Desa Tiku

\begin{tabular}{|c|c|c|c|c|c|c|c|c|}
\hline $\mathrm{Mw}$ & $\mathrm{z}(\mathrm{m})$ & $\mathrm{qc}(\mathrm{kg} / \mathrm{cm} 2)$ & $\mathrm{fr}(\mathrm{kg} / \mathrm{cm} 2)$ & $\mathrm{rd}$ & $\mathrm{CRR}$ & $\mathrm{CSR}$ & MSF & SF \\
\hline \multirow{7}{*}{7} & 0.2 & 40 & 20 & 0.99847 & 0.0833 & 0.0981 & 1.1927 & 1.01 \\
\cline { 2 - 9 } & 0.4 & 40 & 40 & 0.99694 & 0.0833 & 0.0980 & 1.1927 & 1.01 \\
\cline { 2 - 9 } & 0.6 & 45 & 50 & 0.99541 & 0.0875 & 0.0978 & 1.1927 & 1.07 \\
\cline { 2 - 9 } & 0.8 & 55 & 60 & 0.99388 & 0.0860 & 0.0977 & 1.1927 & 1.05 \\
\cline { 2 - 9 } & 1.0 & 45 & 80 & 0.99235 & 0.0875 & 0.0975 & 1.1927 & 1.07 \\
\cline { 2 - 9 } & 1.2 & 65 & 110 & 0.99082 & 0.0885 & 0.0974 & 1.1927 & 1.08 \\
\cline { 2 - 9 } & 1.4 & 70 & 130 & 0.98929 & 0.0955 & 0.0972 & 1.1927 & 1.17 \\
\cline { 2 - 9 } & 1.6 & 85 & 140 & 0.98776 & 0.0885 & 0.0971 & 1.1927 & 1.09 \\
\cline { 2 - 9 } & 1.8 & 100 & 150 & 0.98623 & 0.1055 & 0.0969 & 1.1927 & 1.30 \\
\hline
\end{tabular}

Tabel 3 menunjukkan nilai faktor aman untuk simulasi gempa 7,9 SR. Nilai faktor aman untuk gempa 7,9 SR berkisar antara 0,74-0,95. Gempa skala 7,9 SR sudah mampu memicu likuifaksi di Desa Tiku.

Tabel 3. Momen Gempa 7,9 SR terhadap Nilai SF di Desa Tiku

\begin{tabular}{|c|c|c|c|c|c|c|c|c|}
\hline $\mathrm{Mw}$ & $\mathrm{z}(\mathrm{m})$ & $\mathrm{qc}(\mathrm{kg} / \mathrm{cm} 2)$ & $\mathrm{fr}(\mathrm{kg} / \mathrm{cm} 2)$ & $\mathrm{rd}$ & $\mathrm{CRR}$ & $\mathrm{CSR}$ & $\mathrm{MSF}$ & $\mathrm{SF}$ \\
\hline \multirow{3}{*}{7.9} & 0.2 & 40 & 20 & 0.99847 & 0.0833 & 0.0981 & 0.8755 & 0.74 \\
\cline { 2 - 9 } & 0.4 & 40 & 40 & 0.99694 & 0.0833 & 0.0980 & 0.8755 & 0.74 \\
\cline { 2 - 9 } & 0.6 & 45 & 50 & 0.99541 & 0.0875 & 0.0978 & 0.8755 & 0.78 \\
\cline { 2 - 9 } & 0.8 & 55 & 60 & 0.99388 & 0.0860 & 0.0977 & 0.8755 & 0.77 \\
\cline { 2 - 9 } & 1.0 & 45 & 80 & 0.99235 & 0.0875 & 0.0975 & 0.8755 & 0.79 \\
\cline { 2 - 9 } & 1.2 & 65 & 110 & 0.99082 & 0.0885 & 0.0974 & 0.8755 & 0.80 \\
\cline { 2 - 9 } & 1.4 & 70 & 130 & 0.98929 & 0.0955 & 0.0972 & 0.8755 & 0.86 \\
\cline { 2 - 9 } & 1.6 & 85 & 140 & 0.98776 & 0.0885 & 0.0971 & 0.8755 & 0.80 \\
\cline { 2 - 9 } & 1.8 & 100 & 150 & 0.98623 & 0.1055 & 0.0969 & 0.8755 & 0.95 \\
\hline
\end{tabular}

Tabel 4 menunjukkan nilai faktor aman untuk simulasi gempa 8 SR. Nilai faktor aman untuk gempa 8 SR berkisar antara 0,72-0,92. Gempa skala 8 SR memicu likuifaksi di Desa Tiku. 
Tabel 4. Momen Gempa 8 SR terhadap Nilai SF di Desa Tiku

\begin{tabular}{|c|c|c|c|c|c|c|c|c|}
\hline $\mathrm{Mw}$ & $\mathrm{z}(\mathrm{m})$ & $\mathrm{qc}(\mathrm{kg} / \mathrm{cm} 2)$ & $\mathrm{fr}(\mathrm{kg} / \mathrm{cm} 2)$ & $\mathrm{rd}$ & $\mathrm{CRR}$ & $\mathrm{CSR}$ & $\mathrm{MSF}$ & $\mathrm{SF}$ \\
\hline \multirow{3}{*}{8} & 0.2 & 40 & 20 & 0.99847 & 0.0833 & 0.0981 & 0.8477 & 0.72 \\
\cline { 2 - 9 } & 0.4 & 40 & 40 & 0.99694 & 0.0833 & 0.0980 & 0.8477 & 0.72 \\
\cline { 2 - 9 } & 0.6 & 45 & 50 & 0.99541 & 0.0875 & 0.0978 & 0.8477 & 0.76 \\
\cline { 2 - 9 } & 0.8 & 55 & 60 & 0.99388 & 0.0860 & 0.0977 & 0.8477 & 0.75 \\
\cline { 2 - 9 } & 1.0 & 45 & 80 & 0.99235 & 0.0875 & 0.0975 & 0.8477 & 0.76 \\
\cline { 2 - 9 } & 1.2 & 65 & 110 & 0.99082 & 0.0885 & 0.0974 & 0.8477 & 0.77 \\
\cline { 2 - 9 } & 1.4 & 70 & 130 & 0.98929 & 0.0955 & 0.0972 & 0.8477 & 0.83 \\
\cline { 2 - 9 } & 1.6 & 85 & 140 & 0.98776 & 0.0885 & 0.0971 & 0.8477 & 0.77 \\
\cline { 2 - 9 } & 1.8 & 100 & 150 & 0.98623 & 0.1055 & 0.0969 & 0.8477 & 0.92 \\
\hline
\end{tabular}

Tabel 5 menunjukkan nilai faktor aman untuk simulasi gempa 9 SR. Nilai faktor aman untuk gempa 9 SR berkisar antara 0,53-0,68. Gempa skala 9 SR memicu likuifaksi di Desa Tiku.

Tabel 5. Momen Gempa 9 SR terhadap Nilai SF di Desa Tiku

\begin{tabular}{|c|c|c|c|c|c|c|c|c|}
\hline $\mathrm{Mw}$ & $\mathrm{z}(\mathrm{m})$ & $\mathrm{qc}(\mathrm{kg} / \mathrm{cm} 2)$ & $\mathrm{fr}(\mathrm{kg} / \mathrm{cm} 2)$ & $\mathrm{rd}$ & $\mathrm{CRR}$ & $\mathrm{CSR}$ & $\mathrm{MSF}$ & $\mathrm{SF}$ \\
\hline \multirow{3}{*}{9} & 0.2 & 40 & 20 & 0.99847 & 0.0833 & 0.0981 & 0.6270 & 0.53 \\
\cline { 2 - 9 } & 0.4 & 40 & 40 & 0.99694 & 0.0833 & 0.0980 & 0.6270 & 0.53 \\
\cline { 2 - 9 } & 0.6 & 45 & 50 & 0.99541 & 0.0875 & 0.0978 & 0.6270 & 0.56 \\
\cline { 2 - 9 } & 0.8 & 55 & 60 & 0.99388 & 0.0860 & 0.0977 & 0.6270 & 0.55 \\
\cline { 2 - 9 } & 1.0 & 45 & 80 & 0.99235 & 0.0875 & 0.0975 & 0.6270 & 0.56 \\
\cline { 2 - 9 } & 1.2 & 65 & 110 & 0.99082 & 0.0885 & 0.0974 & 0.6270 & 0.57 \\
\cline { 2 - 9 } & 1.4 & 70 & 130 & 0.98929 & 0.0955 & 0.0972 & 0.6270 & 0.62 \\
\cline { 2 - 9 } & 1.6 & 85 & 140 & 0.98776 & 0.0885 & 0.0971 & 0.6270 & 0.57 \\
\cline { 2 - 9 } & 1.8 & 100 & 150 & 0.98623 & 0.1055 & 0.0969 & 0.6270 & 0.68 \\
\hline
\end{tabular}

Gambar 6 menunjukkan grafik potensi likuifaksi di Desa Tiku. Nilai faktor aman di Desa Tiku berkisar antara 0,53 1,30. Likuifaksi di Desa Tiku terjadi pada lapisan tanah dengan SF 0,53-0,95 $(<1,0)$.

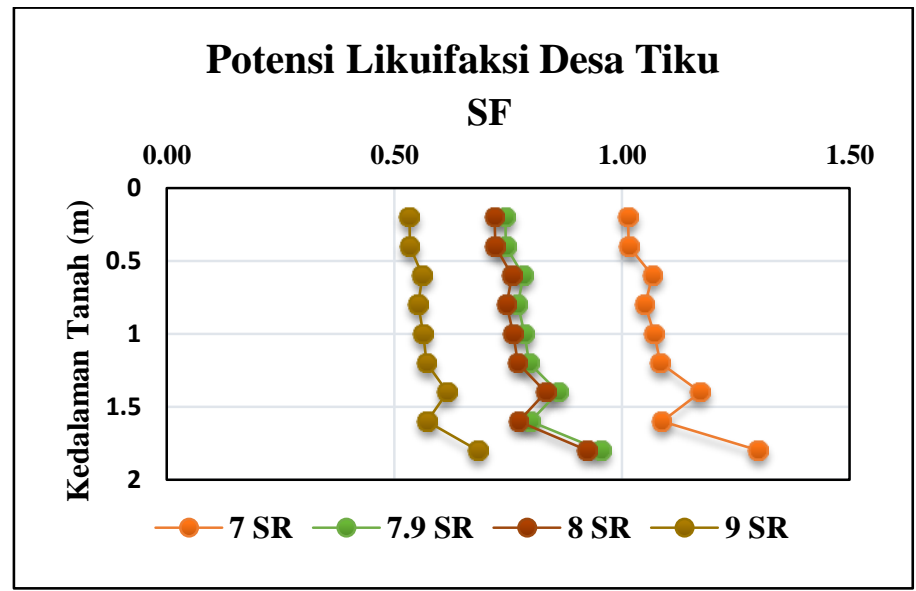

Gambar 5. Grafik Potensi Likuifaksi Desa Tiku

2. Desa Air Bangis

Sondir di Desa Air Bangis dilakukan hingga kedalaman 3,0 m dengan interval 0,2 m. Simulasi dilakukan menggunakan gempa magnitudo $7 \mathrm{SR}-9 \mathrm{SR}$. Tabel 6 menunjukkan nilai faktor aman gempa 7 SR berkisar antara 0,97-4,68. Gempa skala 7 SR sudah mampu memicu likuifaksi di Desa Air Bangis. 
Tabel 6. Momen Gempa 7 SR terhadap Nilai SF di Desa Air Bangis

\begin{tabular}{|c|c|c|c|c|c|c|c|c|}
\hline Mw & $\mathrm{z}$ & $\mathrm{qc}$ & $\mathrm{fr}$ & $\mathrm{rd}$ & CRR & CSR & MSF & SF \\
\hline \multirow[t]{15}{*}{7} & 0.2 & 40 & 10 & 0.99847 & 0.0833 & 0.1026 & 1.1927 & 0.97 \\
\hline & 0.4 & 40 & 20 & 0.99694 & 0.0833 & 0.1024 & 1.1927 & 0.97 \\
\hline & 0.6 & 50 & 50 & 0.99541 & 0.0917 & 0.1023 & 1.1927 & 1.07 \\
\hline & 0.8 & 55 & 70 & 0.99388 & 0.0955 & 0.1021 & 1.1927 & 1.12 \\
\hline & 1.0 & 60 & 80 & 0.99235 & 0.1001 & 0.1019 & 1.1927 & 1.17 \\
\hline & 1.2 & 70 & 90 & 0.99082 & 0.1119 & 0.1018 & 1.1927 & 1.31 \\
\hline & 1.4 & 80 & 100 & 0.98929 & 0.1276 & 0.1016 & 1.1927 & 1.50 \\
\hline & 1.6 & 100 & 120 & 0.98776 & 0.1730 & 0.1015 & 1.1927 & 2.03 \\
\hline & 1.8 & 120 & 140 & 0.98623 & 0.2407 & 0.1013 & 1.1927 & 2.83 \\
\hline & 2.0 & 130 & 150 & 0.9847 & 0.2843 & 0.1012 & 1.1927 & 3.35 \\
\hline & 2.2 & 125 & 160 & 0.98317 & 0.2616 & 0.1010 & 1.1927 & 3.09 \\
\hline & 2.4 & 120 & 170 & 0.98164 & 0.2407 & 0.1008 & 1.1927 & 2.85 \\
\hline & 2.6 & 120 & 180 & 0.98011 & 0.2407 & 0.1007 & 1.1927 & 2.85 \\
\hline & 2.8 & 110 & 190 & 0.97858 & 0.2038 & 0.1005 & 1.1927 & 2.42 \\
\hline & 3.0 & 150 & 210 & 0.97705 & 0.3939 & 0.1004 & 1.1927 & 4.68 \\
\hline
\end{tabular}

Tabel 7 menunjukkan nilai faktor aman untuk simulasi gempa 7,9 SR. Nilai faktor aman untuk gempa 7,9 SR berkisar antara 0,71-3,44. Gempa skala 7,9 SR memicu likuifaksi di Desa Air Bangis.

Tabel 7. Momen Gempa 7,9 SR terhadap Nilai SF di Desa Air Bangis

\begin{tabular}{|c|c|c|c|c|c|c|c|c|}
\hline Mw & $\mathrm{z}$ & $\mathrm{qc}$ & fr & $\mathrm{rd}$ & CRR & CSR & MSF & SF \\
\hline \multirow[t]{15}{*}{7.9} & 0.2 & 40 & 10 & 0.99847 & 0.0833 & 0.1026 & 0.8755 & 0.71 \\
\hline & 0.4 & 40 & 20 & 0.99694 & 0.0833 & 0.1024 & 0.8755 & 0.71 \\
\hline & 0.6 & 50 & 50 & 0.99541 & 0.0917 & 0.1023 & 0.8755 & 0.78 \\
\hline & 0.8 & 55 & 70 & 0.99388 & 0.0955 & 0.1021 & 0.8755 & 0.82 \\
\hline & 1.0 & 60 & 80 & 0.99235 & 0.1001 & 0.1019 & 0.8755 & 0.86 \\
\hline & 1.2 & 70 & 90 & 0.99082 & 0.1119 & 0.1018 & 0.8755 & 0.96 \\
\hline & 1.4 & 80 & 100 & 0.98929 & 0.1276 & 0.1016 & 0.8755 & 1.10 \\
\hline & 1.6 & 100 & 120 & 0.98776 & 0.1730 & 0.1015 & 0.8755 & 1.49 \\
\hline & 1.8 & 120 & 140 & 0.98623 & 0.2407 & 0.1013 & 0.8755 & 2.08 \\
\hline & 2.0 & 130 & 150 & 0.9847 & 0.2843 & 0.1012 & 0.8755 & 2.46 \\
\hline & 2.2 & 125 & 160 & 0.98317 & 0.2616 & 0.1010 & 0.8755 & 2.27 \\
\hline & 2.4 & 120 & 170 & 0.98164 & 0.2407 & 0.1008 & 0.8755 & 2.09 \\
\hline & 2.6 & 120 & 180 & 0.98011 & 0.2407 & 0.1007 & 0.8755 & 2.09 \\
\hline & 2.8 & 110 & 190 & 0.97858 & 0.2038 & 0.1005 & 0.8755 & 1.77 \\
\hline & 3.0 & 150 & 210 & 0.97705 & 0.3939 & 0.1004 & 0.8755 & 3.44 \\
\hline
\end{tabular}

Tabel 8 menunjukkan nilai faktor aman untuk simulasi gempa 7 SR. Nilai faktor aman untuk gempa 8 SR berkisar antara 0,69-3,33. Gempa skala 8 SR memicu likuifaksi di Desa Air Bangis. 
Tabel 8. Momen Gempa 8 SR terhadap Nilai SF di Desa Air Bangis

\begin{tabular}{|c|c|c|c|c|c|c|c|c|}
\hline $\mathrm{Mw}$ & $\mathrm{z}$ & $\mathrm{qc}$ & $\mathrm{fr}$ & $\mathrm{rd}$ & CRR & CSR & MSF & SF \\
\hline \multirow[t]{15}{*}{8} & 0.2 & 40 & 10 & 0.99847 & 0.0833 & 0.1026 & 0.8477 & 0.69 \\
\hline & 0.4 & 40 & 20 & 0.99694 & 0.0833 & 0.1024 & 0.8477 & 0.69 \\
\hline & 0.6 & 50 & 50 & 0.99541 & 0.0917 & 0.1023 & 0.8477 & 0.76 \\
\hline & 0.8 & 55 & 70 & 0.99388 & 0.0955 & 0.1021 & 0.8477 & 0.79 \\
\hline & 1.0 & 60 & 80 & 0.99235 & 0.1001 & 0.1019 & 0.8477 & 0.83 \\
\hline & 1.2 & 70 & 90 & 0.99082 & 0.1119 & 0.1018 & 0.8477 & 0.93 \\
\hline & 1.4 & 80 & 100 & 0.98929 & 0.1276 & 0.1016 & 0.8477 & 1.06 \\
\hline & 1.6 & 100 & 120 & 0.98776 & 0.1730 & 0.1015 & 0.8477 & 1.45 \\
\hline & 1.8 & 120 & 140 & 0.98623 & 0.2407 & 0.1013 & 0.8477 & 2.01 \\
\hline & 2.0 & 130 & 150 & 0.9847 & 0.2843 & 0.1012 & 0.8477 & 2.38 \\
\hline & 2.2 & 125 & 160 & 0.98317 & 0.2616 & 0.1010 & 0.8477 & 2.20 \\
\hline & 2.4 & 120 & 170 & 0.98164 & 0.2407 & 0.1008 & 0.8477 & 2.02 \\
\hline & 2.6 & 120 & 180 & 0.98011 & 0.2407 & 0.1007 & 0.8477 & 2.03 \\
\hline & 2.8 & 110 & 190 & 0.97858 & 0.2038 & 0.1005 & 0.8477 & 1.72 \\
\hline & 3.0 & 150 & 210 & 0.97705 & 0.3939 & 0.1004 & 0.8477 & 3.33 \\
\hline
\end{tabular}

Tabel 9 menunjukkan nilai faktor aman untuk simulasi gempa 7 SR. Nilai faktor aman untuk gempa 9 SR berkisar antara 0,51-2,46. Gempa skala 9 SR memicu likuifaksi di Desa Air Bangis.

Tabel 9. Momen Gempa 9 SR terhadap Nilai SF di Desa Air Bangis

\begin{tabular}{|c|c|c|c|c|c|c|c|c|}
\hline Mw & $\mathrm{Z}$ & $\mathrm{qc}$ & $\mathrm{fr}$ & rd & CRR & CSR & MSF & $\mathrm{SF}$ \\
\hline \multirow[t]{15}{*}{9} & 0.2 & 40 & 10 & 0.99847 & 0.0833 & 0.1026 & 0.6270 & 0.51 \\
\hline & 0.4 & 40 & 20 & 0.99694 & 0.0833 & 0.1024 & 0.6270 & 0.51 \\
\hline & 0.6 & 50 & 50 & 0.99541 & 0.0917 & 0.1023 & 0.6270 & 0.56 \\
\hline & 0.8 & 55 & 70 & 0.99388 & 0.0955 & 0.1021 & 0.6270 & 0.59 \\
\hline & 1.0 & 60 & 80 & 0.99235 & 0.1001 & 0.1019 & 0.6270 & 0.62 \\
\hline & 1.2 & 70 & 90 & 0.99082 & 0.1119 & 0.1018 & 0.6270 & 0.69 \\
\hline & 1.4 & 80 & 100 & 0.98929 & 0.1276 & 0.1016 & 0.6270 & 0.79 \\
\hline & 1.6 & 100 & 120 & 0.98776 & 0.1730 & 0.1015 & 0.6270 & 1.07 \\
\hline & 1.8 & 120 & 140 & 0.98623 & 0.2407 & 0.1013 & 0.6270 & 1.49 \\
\hline & 2.0 & 130 & 150 & 0.9847 & 0.2843 & 0.1012 & 0.6270 & 1.76 \\
\hline & 2.2 & 125 & 160 & 0.98317 & 0.2616 & 0.1010 & 0.6270 & 1.62 \\
\hline & 2.4 & 120 & 170 & 0.98164 & 0.2407 & 0.1008 & 0.6270 & 1.50 \\
\hline & 2.6 & 120 & 180 & 0.98011 & 0.2407 & 0.1007 & 0.6270 & 1.50 \\
\hline & 2.8 & 110 & 190 & 0.97858 & 0.2038 & 0.1005 & 0.6270 & 1.27 \\
\hline & 3.0 & 150 & 210 & 0.97705 & 0.3939 & 0.1004 & 0.6270 & 2.46 \\
\hline
\end{tabular}

Gambar 6 menunjukkan grafik potensi likuifaksi di Desa Air Bangis. Nilai faktor aman di Desa Air Bangis berkisar antara 0,51 - 4,68. Likuifaksi di Desa Air Bangis terjadi pada lapisan tanah dengan SF 0,51-0,97 $(<1,0)$. 


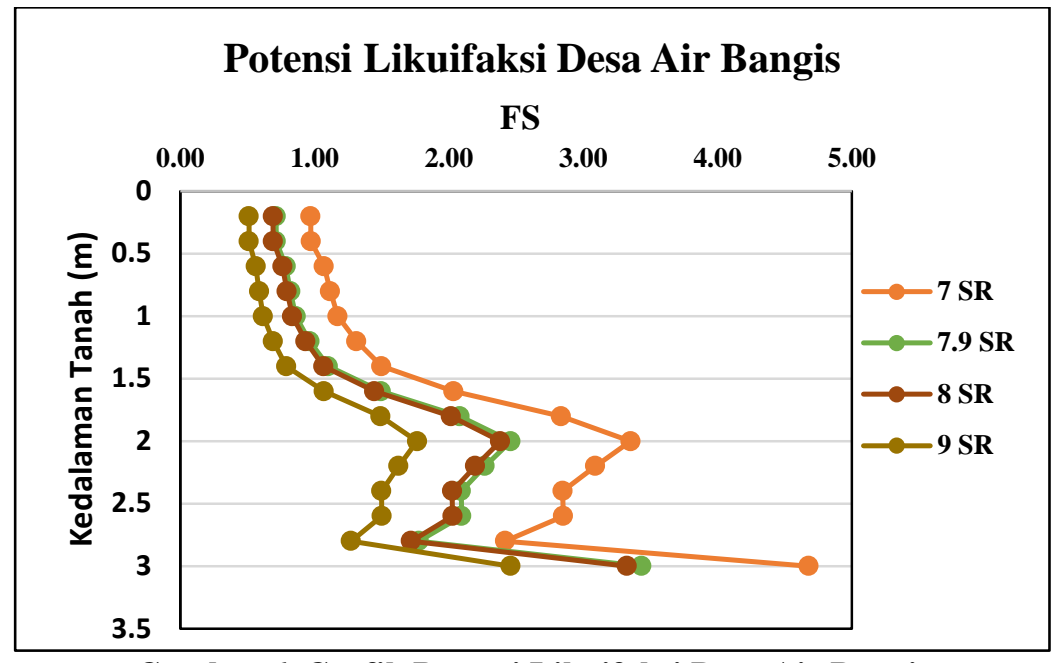

Gambar 6. Grafik Potensi Likuifaksi Desa Air Bangis

3. Desa Sasak

Sondir di Desa Sasak dilakukan hingga kedalaman 3,8 m dengan interval 0,2 m. Simulasi dilakukan menggunakan gempa magnitudo 7 SR - 9 SR. Tabel 10 menunjukkan nilai faktor aman untuk simulasi gempa 7 SR. Nilai faktor aman untuk gempa 7 SR berkisar antara 0,86-3,92. Gempa skala 7 SR sudah mampu memicu likuifaksi di Desa Sasak.

Tabel 10. Momen Gempa 7 SR terhadap Nilai SF di Desa Sasak

\begin{tabular}{|c|c|c|c|c|c|c|c|c|}
\hline Mw & $\mathrm{z}$ & $\mathrm{qc}$ & $\mathrm{fr}$ & $\mathrm{rd}$ & CRR & CSR & MSF & SF \\
\hline \multirow[t]{19}{*}{7} & 0.2 & 40 & 10 & 0.99847 & 0.0833 & 0.1046 & 1.1927 & 0.95 \\
\hline & 0.4 & 35 & 20 & 0.99694 & 0.0792 & 0.1044 & 1.1927 & 0.90 \\
\hline & 0.6 & 30 & 30 & 0.99541 & 0.0750 & 0.1042 & 1.1927 & 0.86 \\
\hline & 0.8 & 35 & 40 & 0.99388 & 0.0792 & 0.1041 & 1.1927 & 0.91 \\
\hline & 1.0 & 30 & 50 & 0.99235 & 0.0750 & 0.1039 & 1.1927 & 0.86 \\
\hline & 1.2 & 50 & 60 & 0.99082 & 0.0917 & 0.1038 & 1.1927 & 1.05 \\
\hline & 1.4 & 50 & 70 & 0.98929 & 0.0917 & 0.1036 & 1.1927 & 1.06 \\
\hline & 1.6 & 55 & 80 & 0.98776 & 0.0825 & 0.1034 & 1.1927 & 0.95 \\
\hline & 1.8 & 60 & 90 & 0.98623 & 0.0916 & 0.1033 & 1.1927 & 1.06 \\
\hline & 2.0 & 65 & 110 & 0.9847 & 0.0916 & 0.1031 & 1.1927 & 1.06 \\
\hline & 2.2 & 80 & 150 & 0.98317 & 0.0955 & 0.1030 & 1.1927 & 1.11 \\
\hline & 2.4 & 100 & 190 & 0.98164 & 0.1001 & 0.1028 & 1.1927 & 1.16 \\
\hline & 2.6 & 110 & 230 & 0.98011 & 0.1055 & 0.1026 & 1.1927 & 1.23 \\
\hline & 2.8 & 140 & 270 & 0.97858 & 0.1276 & 0.1025 & 1.1927 & 1.49 \\
\hline & 3.0 & 130 & 290 & 0.97705 & 0.1730 & 0.1023 & 1.1927 & 2.02 \\
\hline & 3.2 & 120 & 310 & 0.97552 & 0.2038 & 0.1022 & 1.1927 & 2.38 \\
\hline & 3.4 & 115 & 330 & 0.97399 & 0.3352 & 0.1020 & 1.1927 & 3.92 \\
\hline & 3.6 & 110 & 350 & 0.97246 & 0.2843 & 0.1018 & 1.1927 & 3.33 \\
\hline & 3.8 & 130 & 370 & 0.97093 & 0.2407 & 0.1017 & 1.1927 & 2.82 \\
\hline
\end{tabular}

Tabel 11 menunjukkan nilai faktor aman untuk simulasi gempa 7,9 SR. Nilai faktor aman untuk gempa 7,9 SR berkisar antara 0,63-2,88. Gempa skala 7,9 SR memicu likuifaksi di Desa Sasak. 
Tabel 11. Momen Gempa 7,9 SR terhadap Nilai SF di Desa Sasak

\begin{tabular}{|c|c|c|c|c|c|c|c|c|}
\hline $\mathrm{Mw}$ & $\mathrm{z}$ & $\mathrm{qc}$ & $\mathrm{fr}$ & rd & CRR & CSR & MSF & SF \\
\hline \multirow[t]{19}{*}{7.9} & 0.2 & 40 & 10 & 0.99847 & 0.0833 & 0.1046 & 0.8755 & 0.70 \\
\hline & 0.4 & 35 & 20 & 0.99694 & 0.0792 & 0.1044 & 0.8755 & 0.66 \\
\hline & 0.6 & 30 & 30 & 0.99541 & 0.0750 & 0.1042 & 0.8755 & 0.63 \\
\hline & 0.8 & 35 & 40 & 0.99388 & 0.0792 & 0.1041 & 0.8755 & 0.67 \\
\hline & 1.0 & 30 & 50 & 0.99235 & 0.0750 & 0.1039 & 0.8755 & 0.63 \\
\hline & 1.2 & 50 & 60 & 0.99082 & 0.0917 & 0.1038 & 0.8755 & 0.77 \\
\hline & 1.4 & 50 & 70 & 0.98929 & 0.0917 & 0.1036 & 0.8755 & 0.77 \\
\hline & 1.6 & 55 & 80 & 0.98776 & 0.0825 & 0.1034 & 0.8755 & 0.70 \\
\hline & 1.8 & 60 & 90 & 0.98623 & 0.0916 & 0.1033 & 0.8755 & 0.78 \\
\hline & 2.0 & 65 & 110 & 0.9847 & 0.0916 & 0.1031 & 0.8755 & 0.78 \\
\hline & 2.2 & 80 & 150 & 0.98317 & 0.0955 & 0.1030 & 0.8755 & 0.81 \\
\hline & 2.4 & 100 & 190 & 0.98164 & 0.1001 & 0.1028 & 0.8755 & 0.85 \\
\hline & 2.6 & 110 & 230 & 0.98011 & 0.1055 & 0.1026 & 0.8755 & 0.90 \\
\hline & 2.8 & 140 & 270 & 0.97858 & 0.1276 & 0.1025 & 0.8755 & 1.09 \\
\hline & 3.0 & 130 & 290 & 0.97705 & 0.1730 & 0.1023 & 0.8755 & 1.48 \\
\hline & 3.2 & 120 & 310 & 0.97552 & 0.2038 & 0.1022 & 0.8755 & 1.75 \\
\hline & 3.4 & 115 & 330 & 0.97399 & 0.3352 & 0.1020 & 0.8755 & 2.88 \\
\hline & 3.6 & 110 & 350 & 0.97246 & 0.2843 & 0.1018 & 0.8755 & 2.44 \\
\hline & 3.8 & 130 & 370 & 0.97093 & 0.2407 & 0.1017 & 0.8755 & 2.07 \\
\hline
\end{tabular}

Tabel 12 menunjukkan nilai faktor aman untuk simulasi gempa 8 SR. Nilai faktor aman untuk gempa 8 SR berkisar antara 0,61-2,79. Gempa skala 8 SR memicu likuifaksi di Desa Sasak.

Tabel 12. Momen Gempa 8 SR terhadap Nilai SF di Desa Sasak

\begin{tabular}{|c|c|c|c|c|c|c|c|c|}
\hline Mw & $\mathrm{z}$ & $\mathrm{qc}$ & $\mathrm{fr}$ & $\mathrm{rd}$ & CRR & CSR & MSF & SF \\
\hline \multirow[t]{19}{*}{8} & 0.2 & 40 & 10 & 0.99847 & 0.0833 & 0.1046 & 0.8477 & 0.68 \\
\hline & 0.4 & 35 & 20 & 0.99694 & 0.0792 & 0.1044 & 0.8477 & 0.64 \\
\hline & 0.6 & 30 & 30 & 0.99541 & 0.0750 & 0.1042 & 0.8477 & 0.61 \\
\hline & 0.8 & 35 & 40 & 0.99388 & 0.0792 & 0.1041 & 0.8477 & 0.64 \\
\hline & 1.0 & 30 & 50 & 0.99235 & 0.0750 & 0.1039 & 0.8477 & 0.61 \\
\hline & 1.2 & 50 & 60 & 0.99082 & 0.0917 & 0.1038 & 0.8477 & 0.75 \\
\hline & 1.4 & 50 & 70 & 0.98929 & 0.0917 & 0.1036 & 0.8477 & 0.75 \\
\hline & 1.6 & 55 & 80 & 0.98776 & 0.0825 & 0.1034 & 0.8477 & 0.68 \\
\hline & 1.8 & 60 & 90 & 0.98623 & 0.0916 & 0.1033 & 0.8477 & 0.75 \\
\hline & 2.0 & 65 & 110 & 0.9847 & 0.0916 & 0.1031 & 0.8477 & 0.75 \\
\hline & 2.2 & 80 & 150 & 0.98317 & 0.0955 & 0.1030 & 0.8477 & 0.79 \\
\hline & 2.4 & 100 & 190 & 0.98164 & 0.1001 & 0.1028 & 0.8477 & 0.83 \\
\hline & 2.6 & 110 & 230 & 0.98011 & 0.1055 & 0.1026 & 0.8477 & 0.87 \\
\hline & 2.8 & 140 & 270 & 0.97858 & 0.1276 & 0.1025 & 0.8477 & 1.06 \\
\hline & 3.0 & 130 & 290 & 0.97705 & 0.1730 & 0.1023 & 0.8477 & 1.43 \\
\hline & 3.2 & 120 & 310 & 0.97552 & 0.2038 & 0.1022 & 0.8477 & 1.69 \\
\hline & 3.4 & 115 & 330 & 0.97399 & 0.3352 & 0.1020 & 0.8477 & 2.79 \\
\hline & 3.6 & 110 & 350 & 0.97246 & 0.2843 & 0.1018 & 0.8477 & 2.37 \\
\hline & 3.8 & 130 & 370 & 0.97093 & 0.2407 & 0.1017 & 0.8477 & 2.01 \\
\hline
\end{tabular}

Tabel 13 menunjukkan nilai faktor aman untuk simulasi gempa 9 SR. Nilai faktor aman untuk gempa 9 SR berkisar antara 0,45-2,06. Gempa skala 7,9 SR memicu likuifaksi di Desa Sasak. 
Tabel 13. Momen Gempa 9 SR terhadap Nilai SF di Desa Sasak

\begin{tabular}{|c|c|c|c|c|c|c|c|c|}
\hline Mw & $\mathrm{z}$ & $\mathrm{qc}$ & $\mathrm{fr}$ & rd & CRR & CSR & MSF & SF \\
\hline \multirow[t]{19}{*}{9} & 0.2 & 40 & 10 & 0.99847 & 0.0833 & 0.1046 & 0.6270 & 0.50 \\
\hline & 0.4 & 35 & 20 & 0.99694 & 0.0792 & 0.1044 & 0.6270 & 0.48 \\
\hline & 0.6 & 30 & 30 & 0.99541 & 0.0750 & 0.1042 & 0.6270 & 0.45 \\
\hline & 0.8 & 35 & 40 & 0.99388 & 0.0792 & 0.1041 & 0.6270 & 0.48 \\
\hline & 1.0 & 30 & 50 & 0.99235 & 0.0750 & 0.1039 & 0.6270 & 0.45 \\
\hline & 1.2 & 50 & 60 & 0.99082 & 0.0917 & 0.1038 & 0.6270 & 0.55 \\
\hline & 1.4 & 50 & 70 & 0.98929 & 0.0917 & 0.1036 & 0.6270 & 0.55 \\
\hline & 1.6 & 55 & 80 & 0.98776 & 0.0825 & 0.1034 & 0.6270 & 0.50 \\
\hline & 1.8 & 60 & 90 & 0.98623 & 0.0916 & 0.1033 & 0.6270 & 0.56 \\
\hline & 2.0 & 65 & 110 & 0.9847 & 0.0916 & 0.1031 & 0.6270 & 0.56 \\
\hline & 2.2 & 80 & 150 & 0.98317 & 0.0955 & 0.1030 & 0.6270 & 0.58 \\
\hline & 2.4 & 100 & 190 & 0.98164 & 0.1001 & 0.1028 & 0.6270 & 0.61 \\
\hline & 2.6 & 110 & 230 & 0.98011 & 0.1055 & 0.1026 & 0.6270 & 0.64 \\
\hline & 2.8 & 140 & 270 & 0.97858 & 0.1276 & 0.1025 & 0.6270 & 0.78 \\
\hline & 3.0 & 130 & 290 & 0.97705 & 0.1730 & 0.1023 & 0.6270 & 1.06 \\
\hline & 3.2 & 120 & 310 & 0.97552 & 0.2038 & 0.1022 & 0.6270 & 1.25 \\
\hline & 3.4 & 115 & 330 & 0.97399 & 0.3352 & 0.1020 & 0.6270 & 2.06 \\
\hline & 3.6 & 110 & 350 & 0.97246 & 0.2843 & 0.1018 & 0.6270 & 1.75 \\
\hline & 3.8 & 130 & 370 & 0.97093 & 0.2407 & 0.1017 & 0.6270 & 1.48 \\
\hline
\end{tabular}

Gambar 7 menunjukkan grafik potensi likuifaksi di Desa Sasak. Nilai SF di Desa Sasak berkisar antara 0,45 - 3,92. Likuifaksi terjadi di Desa Sasak pada lapisan tanah dengan SF 0,45-0,95 $(<1,0)$.

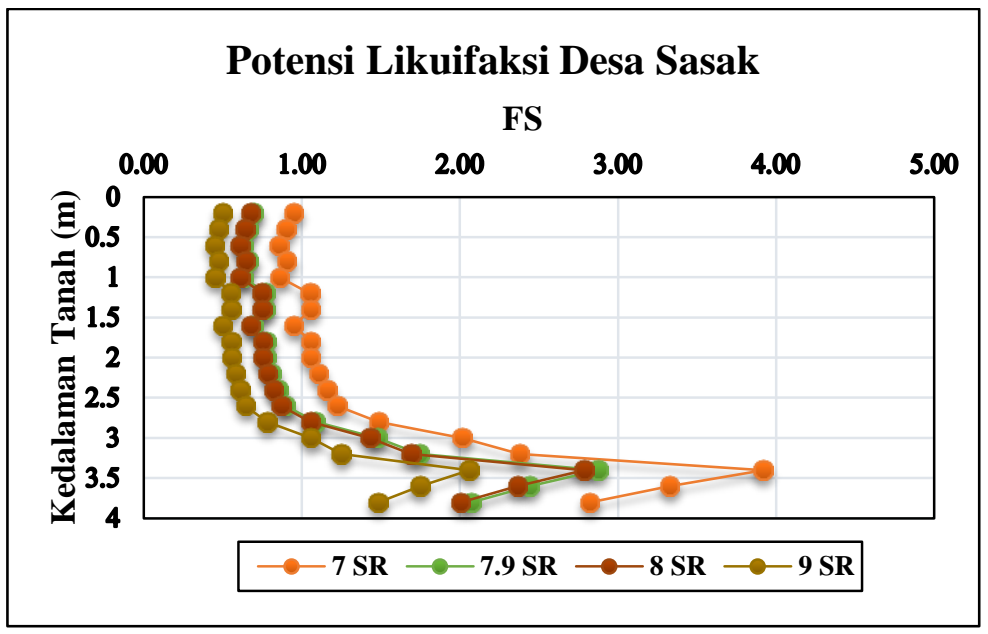

Gambar 7. Grafik Potensi Likuifaksi Desa Sasak

Ketiga lokasi termasuk jenis tanah berpotensi likuifaksi atau bergradasi buruk berdasarkan rentang distribusi ukuran butiran tanah. Jarak lokasi terhadap episentrum Gempa Padang tahun 2009 (7,9 SR) juga mempengaruhi potensi likuifaksi. Hasil penelitian likuifaksi menggunakan geolistrik (Mutmainah dkk., 2020) menunjukkan ketiga lokasi berpotensi likuifaksi karena memenuhi kriteria likuifaksi yaitu elevasi muka air tanah 5-7,5 m ( <10 m), tebal lapisan tanah berpasir 7,5 - $9 \mathrm{~m}$ ( <12 m), dampak gempa 7,5 SR (>5,5 SR) dan berada pada lapisan tanah aluvium kuarter (Dinas ESDM, 2019).

\section{KESIMPULAN}

Hasil simulasi menunjukkan besaran gempa 7 SR sudah mampu memicu likuifaksi di Desa Air Bangis dan Desa Sasak. Simulasi Gempa Padang th.2009 (7,9 SR) menunjukkan potensi likuifaksi $(\mathrm{SF}<1,0)$ di ketiga lokasi yaitu Desa Tiku dengan $\mathrm{SF}=0,53-0,95$; Desa Air Bangis, SF = 0,51 - 0,97 dan Desa Sasak, SF = 0,450,95 . Semakin besar skala gempa dan tegangan efektif 
tanah serta semakin kecil daya dukung tanah maka semakin tinggi potensi likuifaksi.

\section{SARAN}

Perlunya perbandingan analisis likuifaksi menggunakan beberapa metode atau alat. Untuk lokasi rawan likuifaksi diperlukan evaluasi kesesuaian jenis fondasi, jenis perkuatan tanah dan penyusunan zonasi rawan likuifaksi sebagai upaya mitigasi. Kawasan rawan likuifaksi sebaiknya menggunakan fondasi tiang pancang, dilengkapi dengan perkuatan tanah seperti geotekstil atau lapis dasar pasir bersih. Bangunan juga perlu mengikuti standar bangunan tahan gempa dengan pembatasan jumlah lantai. High rise building sebaiknya dibatasi dan hanya untuk kawasan yang relatif stabil.

\section{DAFTAR PUSTAKA}

Bao, X., dkk. 2019. Soil liquefaction mitigation in geotechnical engineering: An overview of recently developed methods. Soil Dynamics and Earthquake

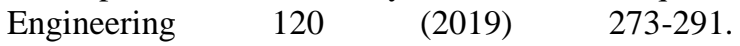
www.elsevier.com/locate/soildyn.

Bray, J.D. \& Jorge, M. 2017. 6th Ishihara Lecture : Simplified Procedure for Estimating LiquefactionInduced Building Settlement. http://www.elsevier.com/openaccess/userlicense/1.0/.

Dinas Energi Dan Sumber Daya Mineral Provinsi Sumatera Barat. 2019. Peta Hidrogeologi Indonesia lembar 0715 Padang dan 0716 Lubuk Sikaping. Padang.

Farhangi, V., Karakouzian M., \& Geertsema, M. 2020. Effect of Micropiles on Clean Sand Liquefaction Risk Based on CPT and SPT.

Hardy, T., Nurdiyanto, B., Ngadmanto, D., \& Susilanto, P. 2015. Karakteristik Lapisan Tanah Berpotensi Likuifaksi Berdasarkan Resistivitas Batuan di Daerah Cilacap. Jurnal Meteorologi dan Geofisika Vol.16. No.1 Tahun 2015:47-56. Jakarta.

Ikhsan, R. 2011. Analisis Potensi Likuifaksi dari Data CPT dan SPT dengan Studi Kasus PLTU Ende Nusa Tenggara Timur. Universitas Indonesia. Depok.

Karamitros, D.K., George, D.B., Yannis, K.C. 2013. Insight Into The Seismic Liquefaction Performance of Shallow Foundations. Journal of Geotechnical and Geoenvironmental Engineering. DOI: 10.1061/(ASCE)GT.1943-5606.0000797. @2013 American Society of Civil Engineers.

Kementerian Pekerjaan Umum. 2012. SNI 1726 : Tata Cara Perencanaan Ketahanan Gempa untuk Struktur Bangunan Gedung dan Non Gedung. Jakarta, Indonesia. Jakarta, Indonesia

Kwa, K. \& Airey, D. 2019. Effect of Fines on The Cyclic Liquefction Behavior in Unsaturated, Well Graded Materials. Soils and Foundations 59 (2019) 857873. https://doi.org/10.1016/j.sandf.2019.03.001.
Lonteng, C. V. D., Balamba, S., Monintja, S., \& Sarajar, A.N. 2011. Analisa Potensi Likuifaksi Berdasarkan Data Pengujian Sondir (Studi Kasus Gor Haji Agus Salim dan Lapai. Padang). Universitas Sam Ratulangi. Manado.

LRSDKP. 2019. Laporan Penelitian Identifikasi Kerentanan dan Inventarisasi Sumber Daya Pesisir di Pesisir Barat Provinsi Sumatera Barat. Padang. Mina, E., Indera, R., \& Sudirman. 2018. Analisa Potensi Likuifaksi Berdasarkan Data SPT (Studi Kasus Proyek Pembangunan Gedung Baru Untirta Sindang Sari). Jurnal Fondasi, Vol.7 No.1. Universits Sultan Ageng Tirtayasa.

Mutmainah, H., Gemilang, W.A., \& Purwono, N.A.S. 2021. Analisa Potensi Likuifaksi di Pesisir Barat Provinsi Sumatera Barat Menggunakan Metode Resistivitas Geolistrik. Prosiding Simposium Nasional Teknologi Infrastruktur Abad ke-21. Yogyakarta. 25-26 Januari 2021. ISBN 978-62391262-1-6.

Sinarta, I.N., \& Basoka I.W.A. 2019. The Potential of Liqefaction Disasters Based on The Geological, CPT, and Borehol Daa at Southern Bali Island. Journal of Applied Engineering Science 17(2019)4, 642, 535 - 540. doi:10.5937/jaes1720794.

Soebowo, E., Tohari, A., Sarah, D., \& Sugianti, K. 2014. Identifikasi Potensi Likufaksi Akibat Gempabumi di Daerah Sumatera, Jawa dan Bali. Prosiding Pemaparan Hasil Penelitian Pusat Penelitian Geoteknologi LIPI Tahun 2014. ISBN : 978-9798636-23-3. p:47-55.

Widyaningrum, R. 2012. Penyelidikan Geologi Teknik Potensi Likuifaksi Daerah Palu, Provinsi Sulawesi Tengah. Kementerian ESDM. Badan Geologi. Pusat Sumber Daya Air Tanah dan Geologi Lingkungan. Bandung.

\section{UCAPAN TERIMA KASIH}

Penelitian ini di danai menggunakan DIPA APBN

Th.2019. Ucapan terima kasih disampaikan kepada Loka Riset Sumber daya \& Kerentanan Pesisir dan Pusat Riset Kelautan, Kementerian Kelautan dan Perikanan. 